\title{
Academies, autonomy, equality and democratic accountability: Reforming the fragmented publicly funded school system in England
}

\author{
Anne West* - London School of Economics and Political Science, UK \\ David Wolfe - Matrix Chambers, UK
}

\begin{abstract}
This article focuses on the transformative academies policy in England. Based on an analysis of documentary evidence, we argue that the policy has resulted in the fragmentation of the state-funded school system and stark variation between academies, with those within multi-academy trusts (MATs) having no legal identity. We examine the variation between funding agreements, the control by central government, the role of MATs and the governance of academies. We propose policy options to improve the current incoherent and fragmented set of provisions, including restoring the legal identity of schools in MATs and allowing academies if they so wish, to convert to maintained schools.
\end{abstract}

Keywords: academies; multi-academy trusts (MATs); funding agreements; law; governance; finance

\section{Introduction}

Since 2000 there has been a rapid and radical transformation of publicly funded schoolbased education in England: over a third of schools - and nearly three-quarters of secondary schools - are now 'academies' rather than 'maintained' by local authorities. Academies are owned and run by not-for-profit private trusts (exempt charities) that register as companies with Companies House and are subject to company law. They are controlled and funded directly by central government by means of a contract - a funding agreement - between a trust (that is, a legal entity) and the Secretary of State for Education (DfE, 2018a), rather than being run by a governing body in accordance with statutory education law, as is essentially the case for maintained schools. In some cases, the trust runs a single stand-alone academy under contract, while others run a number of academies (a multi-academy trust (MAT)) under a single contract (DfE, 2018a, 2018b).

As a result of the academies policy, a transparent national system of maintained schools, where schools operated to a single legal model (with modest variations), had their own legal identity and management, and were overseen by democratically elected local authorities, has been transformed into a highly opaque part-locally administered system and a part-centrally controlled system of academies.

This article adds to the growing body of literature on academies. Recent research has focused on a range of issues including legislation and policy development (for example, Glatter, 2017; Walford, 2014; West and Nikolai, 2017; Wolfe, 2013), academies' socio-economic composition and pupil outcomes (for example, Allen and Higham, 2018; Gorard, 2014; Morris, 2015). Our interest is in the impact that the 
academies policy has had on the English school system. We argue that the policy has resulted not only in the fragmentation of the state-funded school system, but even in stark variation between academies. Fragmentation is also manifest in the varied governance and financial arrangements between academies of different types, and between academies and maintained schools. Furthermore, while one of the main goals of the policy was for schools to have more 'freedom' (DfEE (Department for Education and Employment), 2000; DfE (Department for Education), 2010), this has not been realized for the majority of academies that are within MATs. Finally, while there is local democratic accountability for maintained schools, this is not the case for academies. It has been claimed that 'as government schools, academies have become part of a nationalisation project' (Newsam, 2017: 3). We propose policy options to increase the coherence of the school system, and to reduce fragmentation within a combined academy and state-maintained system as a whole, including enabling the conversion of academies to maintained schools.

The article draws on a range of documentary evidence and secondary academic literature, alongside the direct legal knowledge of one of the authors (DW). The primary documents were selected to cover our broad areas of interest - the academies policy, associated 'freedoms' and variation between academies of different types and maintained schools. The documents comprised legislation (primary and secondary); guidance, policy, administrative and statistical documents produced by the DfE and its predecessors, the Education and Skills Funding Agency (ESFA), and the Office of the Schools Adjudicator (OSA), parliamentary select committee reports, documentary material from law firms and media reports. Following multiple readings of each text, a descriptive summary was created and themes were developed and checked with other texts. Analytical work entailed working within each theme to examine the complexity and variation.

We first provide a brief history of aspects of the English school system, including the development of academies. Second, we discuss fragmentation within the academies programme arising from the funding agreements. Third, we examine the control of academies via central government, in particular, the role played by regional schools commissioners. We then look at the governance of academies by academy trusts: admissions, curriculum, school governance and financial arrangements. Finally, we discuss the key issues and present proposals that could be considered by policymakers to address them.

\section{The English school system over time}

The Education Act 1944 established a national system of state-funded primary and secondary education, comprising schools under the overall supervision of local education authorities (now local authorities). The local authority was responsible for funding ('maintaining') all such schools. (By the School Standards and Framework Act 1998, section 22, the core obligation on a local authority when it comes to 'maintaining' a school is to 'defray its expenses'.) Over the following decades many changes took place, including the emergence (and sometimes disappearance) of various types of maintained schools: community and voluntary-controlled schools (under the direct control of the local authority) and some with more autonomy (particularly over admissions), notably voluntary-aided schools (often associated with religious bodies), grant-maintained schools and foundation schools (Wolfe, 2013).

Perhaps the most fundamental changes were in the establishment of school governing bodies as free-standing legal entities (via the Education Act (No. 2) 1986) and 
in the arrangements for local management of schools (LMS) following the Education Reform Act 1988. Under LMS, schools - in the form of the governing body - were themselves able to make and act on key decisions about matters such as finance and appointments rather than these being under the control of the local authority (Levačic, 1998; West and Pennell, 1997). Despite these changes, the maintained school system remains relatively coherent in terms of governance and structures: maintained schools remain part of local authorities, which make certain decisions under the oversight of elected local councillors.

However, from the early 2000s, academies - originally known as city academies - were introduced by the Labour government, building on city technology colleges (CTCs) set up by the Conservative government from 1986. (The Education Act 1996, section 482, which had provided for CTCs, was amended by the Learning and Skills Act 2000 to provide for 'city academies' to be created by an agreement between the Secretary of State and a 'person'.) The overall goal of these early academies was to replace 'seriously failing schools' (DfEE, 2000: 2; see also West and Bailey, 2013). The academies were not maintained by local authorities, but sponsored by businesses, individuals, churches or voluntary bodies, which contributed to the capital costs and then ran the schools. Revenue costs were met directly by central government and set at a comparable level to maintained schools in the area, with additional funds to cover the cost of services for which the academy would be directly responsible once it was no longer maintained by the local authority (DfEE, 2000). (Academies also received a per pupil grant equivalent to that paid to specialist schools (DfEE, 2000); these were schools set up by the Labour government with a subject specialism (see West and Bailey, 2013).)

The academy sponsors established trusts, namely private companies with charitable status which entered into funding agreements (contracts) with the Secretary of State for Education. In 2009, the requirement for sponsors to make financial contributions to new academies was removed (West and Bailey, 2013). All aspects of school governance for academies were prescribed by the contract, with academies thus initially being freed from the statutory provisions applying to maintained schools in areas such as admissions, exclusions, special educational needs (SEN) and the curriculum (DfEE, 2000; Wolfe, 2011). Instead they were required - by contract - to offer a 'broad and balanced' curriculum, but with special emphasis on at least one area of the curriculum (for example, science and technology, languages, the arts or sport). They were all ability schools, with admissions policies agreed upon with the Secretary of State for Education; they were also permitted to select up to 10 per cent of pupils on the basis of aptitude for the specialism (DfEE, 2000). By the 2010 general election there were 203 sponsored academies out of a total of 3,333 secondary schools (6 per cent) (West and Bailey, 2013).

Following the 2010 general election, the Conservative-led coalition government enacted the Academies Act 2010, providing a bespoke mechanism for maintained schools to 'convert' (a new statutory term) to academy status. (Funding agreements now take effect under the Academies Act 2010, section 1). There was no longer a requirement to specialize in a subject area. A new key policy goal was for academy status to be 'the norm for all state schools, with schools enjoying direct funding and full independence from central and local bureaucracy' (DfE, 2010: 52) and using this apparent autonomy to raise standards and narrow the attainment gap between children from different social groups. Extending greater autonomy to all schools was said to be 'an absolute priority' (DfE, 2010: 54). Initially, only schools considered 'outstanding' by Ofsted could convert, encouraged by considerable financial incentives to do so. 
From April 2011, all schools 'performing well' could apply (West and Bailey, 2013). New academies were also established called 'free schools', but the difference was in name only.

The Education Act 2011 introduced section 6A (the 'free school presumption') (DfE, 2015b) to the Education and Inspections Act 2006: where a local authority sees a need for a new school in its area, it must (other than in exceptional cases) seek proposals to establish an academy (in the form of a free school). This leaves local authorities under a legal duty to secure efficient primary and secondary education in their area (Education Act 1996, section 13) and sufficient schools for providing primary and secondary education (Education Act 1996, section 14), but without any direct legal power to set up new schools themselves in response. In March 2016, the Secretary of State said that all maintained schools would be forced to convert by 2022 (DfE, 2016a), but by May 2016, in the face of opposition from backbench MPs and local government, the government backtracked, saying it would not force academization, although the goal of all schools being academies remains (Adams, 2016).

In January 2018 (DfE, 2018c), 27 per cent of primary schools and 72 per cent of secondary schools were academies, with the majority being converter academies. Altogether 35 per cent of all primary and secondary schools were academies (see Table 1). The proportion of schools that are academies varies from 93 per cent in Bromley to 6 per cent in Lancashire, Lewisham and North Tyneside (National Audit Office, 2018).

Table 1: State-funded primary and secondary schools in England (January 2018)

\begin{tabular}{lrc} 
& Schools & Percentage \\
\hline Primary converter academy & 3,161 & \\
Primary sponsored academy & 1,279 & \\
Primary free school & 152 & $\mathbf{2 7}$ \\
Primary academies & $\mathbf{4 , 5 9 2}$ & $\mathbf{7 3}$ \\
Primary maintained schools & 12,174 & 100 \\
Total primary schools & 16,766 & \\
& & \\
Secondary converter academy & 1,540 & \\
Secondary sponsored academy & 680 & \\
Secondary free school & 171 & $\mathbf{7 2}$ \\
University technical college* & 49 & $\mathbf{2 8}$ \\
Studio school* & 33 & 100 \\
Secondary academies & $\mathbf{2 , 4 7 3}$ & \\
Secondary maintained schools & 963 & 35 \\
Total secondary schools & $\mathbf{3 , 4 3 6}$ & 65 \\
& & 100 \\
\hline Primary and secondary academies & 7,065 & \\
Primary and secondary maintained schools & 13,137 & \\
Total primary and secondary schools & 20,202 & \\
\hline
\end{tabular}

Source: DfE, 2018c

* University technical colleges and studio schools are also types of academy, catering for students aged 14-19. 


\section{Fragmentation and funding agreements}

\section{Funding agreements}

While academies are often talked about generically, there is considerable variation between them as a result of their contractual arrangements. Initially, funding agreements were based on the former CTC agreements and were predominantly concerned with money and property, not pupils or education. 'Model agreements' were subsequently introduced. The content has varied over time - sometimes based on comments made during the course of cases brought to court, sometimes on the political approach to academies, for example. As different types of academy have been introduced, multiple models have emerged; these were only applied to the funding agreements under negotiation at a specific time, with different models applying at different times (Wolfe, 2011; 2014).

One of the most significant changes to funding agreements arose during the passage of the Academies Bill through Parliament, with a requirement for the funding agreement to include SEN obligations. However, this obligation only applied to academies newly created pursuant to the 2010 Act and not to those academies already in existence. (The pre-existing academies (created by the Labour government between 2001 and 2010 using powers under the Education Act 1996, section 482) had different contractual provisions regarding SEN (Wolfe, 2014).)

While the funding agreements have introduced changes across a range of governance- and pupil-related matters for new academies when created, these have had no effect on existing academies. That leaves considerable variation across academies. Existing contracts only change by agreement between the academy trust and Secretary of State, or if overridden by statute. Examples of statutory overriding have included new provisions relating to SEN (Children and Families Act 2014) and to permanent exclusions (School Discipline (Pupil Exclusions and Reviews) (England) Regulations 2012).

\section{Stand-alone academies, chains and MATs}

Most academies, both sponsored and converted, are now in chains rather than being stand-alone. However, the term 'chain' has no formal legal meaning and is used inconsistently. It has been used to describe stand-alone academies grouped under an umbrella trust, stand-alone academies in collaborative partnerships and academies run by MATs (Carter and Coley, n.d.; see also West and Wolfe, 2018). The DfE has used the term 'chain' where a single 'sponsor' runs several academies each with its own funding agreement (DfE, 2015a), but the term is not used in the DfE's Governance handbook: For academies, multi-academy trusts and maintained schools (DfE, 2017a).

In terms of freedom for schools and specifically who decides what, the main difference is between a MAT and other arrangements: with a MAT, there is just one legal entity, with one set of trustees. In November 2017, of the 6,100 academies established at that time, 1,668 were stand-alone academies (27 per cent) and 4,432 schools were in MATs (73 per cent) (DfE, 2018d).

Schools run by a MAT have no separate legal identity, being instead, simply the local site through which the MAT delivers the provision required by the central contract. Any local governing body only has the powers given to it by the MAT (including potentially acting in only an advisory role with no decision-making role at all) (DfE, 2017a). This means that governors and staff in academies in MATs are now in a position similar to that which prevailed for maintained schools before 1988, when 
the local authority had more control over the running of schools. Academies run by MATs do not have the autonomy and ability to make the local (school-based) decisions that maintained schools have enjoyed from 1988, and that stand-alone academies still enjoy.

\section{Schools and their destiny}

The governance structure in a particular academy may have little to do with its current situation or needs: a maintained secondary school considered to be failing prior to the Academies Act 2010 could have been forcibly converted to a stand-alone academy with a sponsor; a school deemed 'outstanding' after July 2010 might have volunteered to convert into a stand-alone academy; and maintained schools struggling since then may have been forced into a MAT. Each may then be locked into a particular contractual arrangement - potentially as a result of one single historic bad or good Ofsted report. Single academies that retain a separate legal identity can contemplate changing the arrangement, for example to become a MAT. But a school in a MAT no longer exists as a legal entity so cannot decide to, say, change MATs, any more than a Tesco store can decide to become an Aldi.

Andrew Adonis, the Labour minister who oversaw academy creations prior to 2010 stated: 'Converter academies which have joined chains can leave them pretty well at will since there is rarely an integral governance dimension' (Adonis, 2012: 206). But this ignores the fact that an academy that has chosen to become part of a MAT does not exist as a legal entity and so is not in a position to make such a decision.

In March 2015, Tristram Hunt, then Shadow Education Minister, was concerned for the 'outstanding school leader trapped in a near unbreakable bond with a poor or failing chain', and noted that 'the Government has never set out a process for good schools to "float off" from poor chains' (Hunt, 2015: 9; see also West and Wolfe, 2018). But this would need schools in MATs to be reinstated as legal entities. Graham Brady, chairman of the 1922 Committee, talked in 2016 of helping schools to leave academy trusts (Helm, 2016): this too implies recreating schools as individual legal entities.

\section{Central government control and regional schools commissioners}

Academy funding agreements are legally contracts between the academy trust and the Secretary of State for Education. When academies were first established, the Secretary of State delegated the day-to-day exercise of powers to civil servants, including the power to enter into contracts, the power to vary them and to exercise the powers they give.

However, from 2014, eight Regional Schools Commissioners (RSCs) were appointed as DfE civil servants, with responsibility for approving new academies and intervening to address underperformance in academies. From 2015, the RSCs became responsible for approving the conversion of underperforming maintained schools to academies and deciding on sponsors. Subsequent legislation (Education and Adoption Act 2016) provided the Secretary of State with new powers to intervene in both maintained schools and academies; these powers were then exercised by RSCs on behalf of the Secretary of State. The RSCs' responsibilities also include encouraging organizations to become academy sponsors, taking decisions on the creation and growth of MATs and making recommendations to ministers on free school applications. RSCs report to the National Schools Commissioner, who also leads the relationship with a small group of large sponsors (Foster and Long, 2017; DfE, 2016b). 
RSCs thus exercise significant powers and responsibility with respect to both academies and maintained schools, but with little transparency, democratic accountability or public or parliamentary scrutiny of their actions. The ESFA, an executive agency sponsored by the DfE, has overall responsibility for funding and financial matters.

\section{Governance of academies}

As we have seen, there is a mixed economy of state-funded schools, including maintained schools (free-standing legal entities maintained by local authorities) and academies of different types, including stand-alone academies and MATs. An original aim of allowing schools to convert to academy status was said to be that academies would have more autonomy than other schools, partly in not being maintained by local authorities and partly in the relaxation of the particular requirements that applied to them as schools (DfE, 2010). Thus, academies are not obliged to follow the national curriculum (unlike maintained schools), the extant model funding agreement does not require teachers in academies to have qualified teacher status, academies are not obliged to pay teachers in accordance with the School Teachers Pay and Conditions statutory guidance and academies are responsible for their own admissions (unlike community and voluntary-controlled schools). Likewise, policies regarding the capability of staff and teacher appraisal are required by maintained schools, but not by academies. Certain information must be published on the websites of maintained schools; however, whether or not such information is published on an academy's website varies according to the funding agreement (DfE, 2014a).

We focus below on four key areas of difference between academies and maintained schools, and between academies of different types: admissions, the curriculum, governance and financial matters.

\section{Admissions}

Stand-alone academies are responsible for their own admissions, although the process is coordinated by local authorities and subject to statutory guidance and a school admissions code. While some academies adopt the same oversubscription criteria as community schools, others have complex arrangements. As with other schools responsible for their own admissions - voluntary-aided and foundation - decisionmaking takes place behind closed doors, unless the academy trust requests that the local authority takes on this role (West and Hind, 2016). The Academies Commission reported that 'numerous submissions to the Commission suggest some academies are finding methods to select covertly' (Academies Commission, 2013: 65). According to the OSA arrangements for schools that are their own admission authority, such as academies, are less clear than those for community and voluntary-controlled schools, where the local authority is the admission authority (OSA, 2015; see also West et al., 2011).

The admission arrangements for academies run by MATs are ultimately for the MAT to decide, although they are operationally determined in different ways. The MAT may directly determine the arrangements for all the academies it runs, it may set parameters within which the local governing bodies of individual schools determine arrangements locally, or it may delegate the determination of arrangements to individual governing bodies entirely. However, the roles of the academy trust and local governing bodies are not always clearly set out or understood by the parties concerned; this can make it difficult to ascertain whether admission arrangements 
have been determined as legally required (OSA, 2016). A number of objections to the OSA have concerned MATs, in which secondary schools prioritize children from primary schools run by the same MAT, regardless of local links, and where the schools are outside what is felt to be a school's normal catchment area. This affects local authority planning, and can also lead to a fall in the number of successful preference allocations, an increase in transport costs and insufficient places within a local area (OSA, 2018).

\section{Curriculum}

Unlike maintained schools, academies do not have to follow the national curriculum; instead they are merely required to offer a broad and balanced curriculum, including English, mathematics, science and religious education (RE). There are some controls - the DfE model funding agreement has been changed so that more newly created academies cannot teach pseudoscience and must teach evolution. There are also new rules (but again applying only to academies created after the particular model was introduced) to restrict the religious ethos from extending beyond admissions, RE and assemblies (Wolfe, 2014). The academy trust must also ensure that principles are promoted that support fundamental British values (DfE, 2014b).

Stand-alone academy trusts have autonomy over the curriculum within these parameters. However, academies within a MAT do not have such autonomy: MATs may seek to standardize the schools they run, giving less freedom and flexibility than the schools enjoyed when they were maintained schools. Research has found that most MATs prescribe the curriculum to some extent, but permit some flexibility in terms of how individual academies teach and deliver the curriculum (Cirin, 2017).

\section{School governance}

In maintained schools, the governing body (itself a free-standing legal entity) runs the school, setting its ethos and vision, appointing the head teacher, managing the finances and so on. The composition of such governing bodies is set by statute (DfE, 2017b) and anyone appointed to the board must have the skills required for effective governance. Decisions are taken by governors whose appointment is laid down by regulations, and meetings of the governing body must be reported on (The School Governance (Roles, Procedures and Allowances) (England) Regulations 2013).

By way of contrast, academies have autonomy as regards their trustees and governance arrangements. The DfE 'sets very few requirements relating to the constitution of the Board of Trustees of trusts into which it is prepared to enter a funding agreement' (DfE, 2017b: 44) although the Board of Trustees must include at least two elected parent trustees (in a MAT these can be at board level or on each local governing body). Decisions in academies are often taken by trustees whose appointment is opaque, and through processes that are not subject to rules on openness that apply to maintained schools: there is no transparency regarding crucial aspects of decision-making - for example, regarding the curriculum, expenditure and procurement.

There are further differences between stand-alone academies and academies within a MAT. Academy trustees are responsible for running a stand-alone academy. However, with a MAT there is just one legal entity, with one set of trustees responsible for all schools in the trust. Any school 'governing body' that the MAT puts in place is at most a committee of the MAT trustees with only those powers (if any) they delegate to it. The scheme of delegation can be varied by the MAT at will, so changing the 
degree of local management. Governing bodies (where they exist at all) of academies run by MATs have considerably less decision-making power and freedom than other academies and maintained schools. Finance, the appointment of the head teacher, strategy and so on are matters over which the MAT has ultimate control.

While some MATs, for example United Learning (2018) and Ark (2018), have retained school governing bodies, at least one, E-ACT, has explicitly scrapped the notion of a school governing body for the 25 academies that it runs (Dickens, 2016). Many individual schools now have relatively little (if indeed any) control over key decisions, including those relating to pay, appraisal, the curriculum, pedagogy and behaviour management (NASUWT, 2016).

This opens up a further question as to whether academies in MATs remain, in law, 'schools' at all, or whether for many, the MAT itself is actually a 'school' operating on a split-site basis. This is because, in law, a school is essentially defined as an institution providing primary or secondary education, or both (Education Act 1996, section 4). The definitional focus therefore shifts to the notion of an institution. At what point does a split-site school become (in law) two schools or vice versa? This was the issue when Tonbridge Grammar School (which converted to academy status in 2011) proposed an 'annexe' ten miles away in Sevenoaks. Was it a single, split-site school or a newly created grammar school (which would not have been allowed under the ban on new grammar academies coming from the Academies Act 2010)? The application was only allowed when harmonized and integrated governance arrangements amounted to expansion (rather than a new school) (Coughlan, 2015).

Applying this analysis to MATs opens the possibility that a MAT retaining much or all decision-making at the centre is actually in law a split-site school rather than a central MAT that runs a group of schools. In other words, what have been thought of as schools have not only ceased to exist as legal entities (and thus lost local control), but have also ceased to be institutions in their own right and ceased to be schools at all, instead simply becoming sites or branches of the MAT.

A further area of concern relates to the lack of transparency and public process as regards the divestment of schools. Thus, in 2017, the Wakefield City Academies Trust (WCAT) comprising 21 academies divested itself of its schools following concerns raised about the schools' educational standards (BBC, 2017). The Chair of the House of Commons Education Committee, Robert Halfon, noted: 'It seems to us that parents, staff and students are in the dark over who is running their schools and that decisions are being taken behind closed doors. Parents seemed to be the last people to know about the imminent collapse of ... [WCAT]' (Halfon, 2018: 1).

When a MAT divests itself of its schools, the DfE has to 'broker' the schools into (that is, arrange for them to be run by) another MAT. Rebrokering involves an academy trust being asked by the RSC to transfer one or more of its schools to another trust: first, if the academy is rated as inadequate by Ofsted; second, if it is deemed to be 'coasting'; or third, if the trust has failed to comply with a termination warning notice issued under its funding agreement (BrowneJacobson, 2017). The 'rebrokering' involves no consultation with parents or any other public process. Complications can also arise when a MAT divests itself of a school and leaves a community without a school to serve the local population. In May 2017, the Academies Enterprise Trust decided to close Sandown Academy on the Isle of Wight, because of falling numbers. The normal procedure would have been a rebrokering process (as above); however, in this case, the local Conservative council put forward a proposal to close the academy and create a new council-run school. This was approved by the government (BBC, 2018). This was necessary as under current legislation it is not possible for an academy 
to convert to a maintained local authority school - and in any case, an academy that is part of a MAT has no legal identity.

\section{Financial arrangements}

The accounts of an academy trust must be audited by external auditors. However, the accounts do not provide a detailed account of how (public) money is spent. This is in contrast to maintained schools, which must provide the local authority with an annual financial statement, presented in accordance with approved headings and subheadings as laid out by statute (Consistent Financial Reporting (England) Regulations 2012) and in compliance with the established accounting practices of the local authority (DfE, 2018e). Local authorities in turn are required to send these statements to the Secretary of State (DfE, 2018e).

The regulations to which academy trusts must adhere are very different. As companies they must produce audited accounts, and as charities they must maintain accounting records and provide publicly accessible accounts in line with the Statement of Recommended Practice for charities. It is also a condition of academy trusts' company and charitable status that they must file their annual accounts with Companies House so that they can be accessed by the public, and provide a copy of the accounts to anyone who requests them (ESFA, 2017a).

Unlike maintained schools, academy trusts are independent institutions, and trusts have autonomy over financial transactions. The Academies Financial Handbook contains specific guidance regarding for example, procurement processes, related party transactions, and probity in the use of public funds (ESFA, 2017a). Nevertheless, concerns have been expressed about how public money is being used by academy trusts - for example, senior staff not being on the payroll and procurement procedures not being carried out in accordance with the Academies Financial Handbook (see, for example, ESFA, 2017b, 2017c).

More specifically, MATs and stand-alone academies are responsible for setting the salaries of their staff and are not bound by the School Teachers Pay and Conditions statutory framework. The House of Commons Committee of Public Accounts (HC PAC, 2018: 6) expressed concerns that some academy trusts appeared 'to be using public money to pay excessive salaries'. It noted that the average annual salary of a head teacher in an academy was $£ 92,000$; for a maintained school it was $£ 88,000$. However, in 2015-16 there were 102 instances of trustees employed the trust being paid salaries which were in excess of $£ 150,000$ (DfE, 2017e). The PAC noted that 'Unjustifiably high salaries use public money that could be better spent on improving children's education, and do not represent value for money' (HC PAC, 2018: 11).

Academy trusts, as employers, may also have to enter into legal settlement agreements. One trust had a number of employment tribunal cases related to unlawful discrimination and victimization that its staff filed against it. As part of settlement resolutions, the trust paid out tens of thousands of pounds in compensation. Although academy trusts are required to publish annual expenditures in an open and transparent manner, in this case the trust hid the amount of public funds it had used to settle allegations levelled against it, ignoring the criteria that must be applied before public funds are used in settlement agreements (Public Concern at Work, 2018).

Academy trusts need to procure goods and services for their schools. One way in which they might do this is via related party transactions. These are business arrangements between an academy trust and body with which those responsible for the governance of an academy trust might have a personal connection; they can include family members. Academy trusts undertook over 3,000 of such transactions worth a 
total of $f 120$ million in 2015-16 (HC PAC, 2018). The DfE reported to the PAC that 40 per cent of academy trusts had related party transactions involving the academy's head teacher or governors. The HC PAC (2018: 10) noted:

We heard of related party transactions where the rules were not properly followed, or where there were doubts about the propriety of the transactions. For example, Wakefield City Academies Trust purchased IT services worth $£ 316,000$ from a company owned by the Chief Executive of the Trust, and paid a further $£ 123,000$ for clerking services provided by a company owned by the Chief Executive's daughter.

In light of the divestment of its schools by the WCAT, the Chair of the Education Committee also expressed his concern about asset stripping: 'We are particularly concerned by the extent to which failing trusts are stripping assets from their schools' (Halfon, 2018: 1).

In addition, the PAC reported problems with related party transactions at the Bright Tribe Academy Trust that resulted in schools being removed from the trust (HC PAC, 2018). Other concerns were also raised: parents and campaigners wanting information on the extent and management of asbestos in a school in Whitehaven in Cumbria, were required to submit a Freedom of Information request for the plan, held in Greater Manchester (ibid.). In the case of another academy, the founder who was a former teacher was ordered to repay $£ 35,000$ after being sentenced to prison for defrauding the school.

\section{Discussion and legal and policy options}

\section{Discussion}

The implementation of the academies policy has resulted in the fragmentation of the state-funded school system: there is variation between academies of the same type and of different types, and between academies and maintained schools. This is clearly seen in admissions, curriculum, governance and financial arrangements.

Despite the academy programme having been initially driven by a wish to give schools freedom and autonomy, those (the majority of academies) that are now run by MATs have no freedom - they do not even exist as legal entities to enjoy such freedoms. As for transparency, decisions in maintained schools are taken by governors through meetings, which must be publicized and reported on. In academies they are often taken by trustees; their appointment is opaque and processes and meetings are not subject to the rules on openness applicable to maintained schools. Academies are not required to provide the same level of detail in financial reports as maintained schools, raising concerns regarding the use of funds.

Decisions for maintained schools are taken by local authorities under the oversight of elected local councillors who operate in meetings subject to public participation obligations. However, decisions for academies are taken by the eight RSCs: individuals appointed by central government, who exercise considerable power without any local democratic oversight or requirement for open process. This includes decisions about opening and closing academies, or rebrokering them from one MAT to another. Local authorities remain under a duty to ensure there are sufficient schools in their areas, but have no direct power to do anything about it.

Similarly, changes to maintained schools, such as opening them, closing them, expanding them and changing the range of pupils for whom they make provision, 
involves a public process (public notices, opportunity to object and so on). This is not so with academies: the MAT or RSC (depending on the issue) can simply make a decision as to how to proceed.

\section{Legal and policy options}

The issues we have discussed raise questions as to how the current fragmented school system could be made more coherent. We would argue that the desired policy goal is for there to be a common framework or rule book for all state-funded schools - academies of different types and maintained schools. The principles underpinning a common framework should be coherence across the system as a whole in order to deliver equality of opportunity (Silver, 1973) for pupils in terms of access to academies and in terms of the teaching on offer (both the curriculum and staff qualifications). Further principles should be those of transparency in terms of process and accountability in terms of both process and the use of public money.

Leading from these principles we offer some proposals and possible mechanisms for improvement. We suggest that the current entirely incoherent and fragmented set of provisions should be brought together in a single framework around different aspects of school governance. Such a framework could be more or less prescriptive for each area, as considered appropriate. One option would be a wholesale statutory conversion of academies into, or back into, maintained schools. What we describe below seeks to address many of the main issues with academies as we describe them here, but without the same level of disruption and cost.

There is a strong case to be made for simplifying admissions arrangements to academies to ensure alignment between maintained schools and academies, and academies created at different points in time. This would improve equality of opportunity in terms of access to schools for all children, including those with SEN. Admissions arrangements should be subject to local agreement and should be administered by the local authority on behalf of all schools to ensure a degree of democratic accountability - it is important that decisions are not taken by schools that have a vested interest in recruiting a particular mix of pupils (West and Hind, 2016). Furthermore, the Local Government Ombudsman has jurisdiction in relation to admission and exclusion panels run by maintained schools, but not those run by academies: there is no apparent justification for this difference and it means that parents do not have equal access to this form of redress. As regards the curriculum, there would seem to be a prima facie case for all schools to be required to teach broadly the same curriculum in order to ensure equality of educational opportunity.

In addition, there is also a strong case for governing bodies of all publicly funded schools, academies and maintained schools, to have a common format and powers, including restoring to academies the requirements for parental, staff and community involvement, so improving local accountability. This would require statutory intervention. Parliament would set the overall framework and override the extant incoherence between maintained schools and academies, and between academies. A model for this is the common framework for SEN and exclusions introduced for academies and maintained schools (see above). A similar approach could also be adopted with regard to teachers' pay and conditions.

There is also a need for more transparency regarding the governance of academy trusts. Rules making it obligatory for the trust to publish its policy for pupils with SEN could be considered. At present, while academies and free schools should publish an online report on their policy for pupils or students with SEN and how they put the policy 
into effect (DfE, 2017c), a maintained school must publish an SEN information report on the school's policy for pupils with SEN, and should update it annually (DfE, 2017d).

Information about the expenditure of individual academies should be required in the same format as for maintained schools. MATs supply their financial data to the DfE at trust level but, to enable transparency, they could separate out expenditure at a central level from school level. A simple statutory framework could be introduced to apply to both academies and maintained schools. This should also help ensure that public money is used appropriately.

With the advent of MATs, the notion of what it means to be a school and the idea that schools have autonomy and some existence as organizations has been discarded. To address this anomaly would require the reinstatement of the legal identity of all schools currently run by MATs and for there to be a contract for each academy. This is important not only for a coherent system, but also because restoring the autonomy and legal identity of schools could allow for the mobility of academies between MATs.

Assuming the continuation of academy-type entities, a further possibility would be to standardize by statute the contractual arrangements, rather than allowing the existing multiplicity of different contracts, to ensure coherence across the system. In Sweden, for example, where a significant proportion of schools are run by private bodies and funded by the state, all licences (contracts) are broadly similar: older licences are transferred in line with changes in legislation, which also means that an operator is unable to invoke the wording or the terms of an old licence (West and Nikolai, 2017).

To restore the linkage with local authorities, the contracts under which academies - newly separated from MATs - operate should be with the local authority rather than the Secretary of State. The local authority would then have no greater power over the academy than does the RSC at present, but it would restore a local connection and democratic oversight. This would reduce the centralization of power that has taken place (Glatter, 2017; Newsam, 2017; West, 2015). There would be no basis for a complaint that government was taking back greater control over schools. There would simply be a shift from central government (and RSCs) to local government: what might be called localism. For the same reason, there is a case to be made for the presumption that a free school should be removed when a new school is needed.

This would create a range of issues to be considered, such as the continuing role of the existing MAT organizations. Where they add real value (in supporting the local running of schools, for example) the MAT organizations could continue as a service that individual schools could buy into, just as maintained schools can choose to buy in support services from the local authority or from external providers. Those academy schools currently within MATs would regain the freedom - once newly constituted as legal entities - to decide where to purchase the support they needed (as do maintained schools and stand-alone academies).

Taken together, these measures would deal with the fragmentation and associated problems that we have described. A new legal framework could ensure that maintained schools and academies adhered to the same rules, with the same obligations regarding admissions, the curriculum, governance and funding. However, they would still leave in place two parallel strands overall: maintained schools and academies, albeit with both linked to local authorities (rather than central government) and with common overall requirements around the specifics of governance and operations. Stopping there would have the attraction to policymakers of not actually changing the core legal notion of an academy - a school run by a trust under contract with the state - and so would be a relatively modest but nonetheless powerful step to take. 
A further step, which policymakers might wish to pursue, would be to allow academies (newly reinstated as separate legal entities) if they so wished, to convert into, or back into maintained schools. At present, the only way an academy can become a maintained school again is for the academy to close and for the local authority to then open a new maintained school.

A new legal framework directly enabling such a transition would be required. A bespoke legal mechanism could be devised by which a school, reinstated as a legal entity, could make the modest additional step of becoming a maintained school again. Wolfe (2013) has proposed that academies could become voluntary-aided schools these schools, like academies, own or lease their own premises, so any conversion would not need to concern itself with potentially expensive property transfer. And Newsam (2017) has suggested that academy trustees could be invited to become trustees of a revised form of voluntary-aided school. If there were a political will to do so more quickly, that process could be made compulsory (Hatcher, 2018) as opposed to permissive.

In conclusion, our proposals would enable policymakers to address the fragmentation of the schools system, which has arisen as a result of the way in which the academies policy has developed over time. These proposals would ensure that there is a more coherent publicly funded school system, which offers equality of opportunity in terms of access to schools and teaching (staff qualifications and curriculum), is transparent as regards governance and financial matters, and is democratically accountable at a local level.

\section{Acknowledgements}

We would like to thank the two anonymous reviewers of an earlier version of this article for their comments. We are also grateful to Public Concern at Work and for advice on school finance provided by a former local authority officer.

\section{Notes on the contributors}

Anne West is Professor of Education Policy in the Department of Social Policy at the London School of Economics and Political Science; she is also Director of the Education Research Group. Her research focuses on education policy in England and in comparative context, and the financing of school-based education and early years education. She has published extensively in the field of education policy.

David Wolfe has been a member of a local education authority and a governor at a range of schools and colleges. As a barrister at Matrix, he has specialized for 25 years in education law issues, including school governance and organization. David has advised many people, groups and organizations on academies. He was involved in most of the major court cases concerned with the establishment and operation of academies.

\section{References}

Academies Commission (2013) Unleashing Greatness: Getting the best from an academised system. London: RSA / Pearson.

Adams, R. (2016) 'Government drops plan to make all schools in England academies'. The Guardian, 6 May. Online. https://tinyurl.com/hpyfgyz (accessed 21 November 2018).

Adonis, A. (2012) Education, Education, Education: Reforming England's schools. London: Biteback Publishing. 
Allen, R. and Higham, R. (2018) 'Quasi-markets, school diversity and social selection: Analysing the case of free schools in England, five years on'. London Review of Education, 16 (2), 191-213.

Ark (2018) Ark Schools Accountabilities Framework. London: Ark. Online. https://tinyurl.com/ ybkzy9p7 (accessed 21 November 2018).

BBC News (2017) 'Wakefield City Academies Trust pulls out of 21 schools'. BBC News, 8 September. Online. www.bbc.co.uk/news/uk-england-leeds-41198403 (accessed 16 November 2018).

BBC News (2018) 'Isle of Wight council-run school plan gets government approval'. BBC News, 21 February. Online. www.bbc.co.uk/news/uk-england-hampshire-43143982 (accessed 16 November 2018).

BrowneJacobson (2017) FAQs - academy re-brokerage, 10 August. https://www.brownejacobson. com/education/training-and-resources/guides/2017/08/faqs-academy-re-brokerage (accessed 17 December 2018).

Carter and Coley (n.d.) 'Different types of academy chains'. Online. https://tinyurl.com/yasft3qc (accessed 21 November 2018).

Cirin, R. (2017) Academy Trust Survey 2017: Research report. London: Department for Education. Online. https://tinyurl.com/y97ysvd2 (accessed 21 November 2018).

Coughlan, S. (2015) 'First "new" grammar school in 50 years'. BBC News, 15 October. Online. www.bbc.co.uk/news/education-34535778 (accessed 16 November 2018).

DfE (Department for Education) (2010) The Importance of Teaching: The Schools White Paper 2010. London: Department for Education. Online. https://tinyurl.com/qcast5r (accessed 21 November 2018).

DfE (Department for Education) (2014a) Statutory Policies for Schools: Advice on the policies and documents that governing bodies and proprietors of schools are required to have by law. London: Department for Education. Online. https://tinyurl.com/y97z294a (accessed 21 November 2018).

DfE (Department for Education) (2014b) Improving the Spiritual, Moral, Social and Cultural (SMSC) Development of Pupils: Supplementary information: Departmental advice for independent schools, academies and free schools. London: Department for Education.

DfE (Department for Education) (2015a) Measuring the Performance of Schools within Academy Chains and Local Authorities (Statistical Working Paper SFR 09/2015). London: Department for Education.

DfE (Department for Education) (2015b) The Free School Presumption: Departmental advice for local authorities and new school proposers. London: Department for Education.

DfE (Department for Education) (2016a) Educational Excellence Everywhere. London: Department for Education.

DfE (Department for Education) (2016b) Regional Schools Commissioners Decision Making Framework. London: Department for Education.

DfE (Department for Education) (2017a) Governance Handbook: For academies, multi-academy trusts and maintained schools. London: Department for Education.

DfE (Department for Education) (2017b) The Constitution of Governing Bodies of Maintained Schools: Statutory guidance for governing bodies of maintained schools and local authorities in England. London: Department for Education.

DfE (Department for Education) (2017c) 'What academies, free schools and colleges should publish online'. Online. https://tinyurl.com/yau6nnuy (accessed 21 November 2018).

DfE (Department for Education) (2017d) 'What maintained schools must publish online'. Online. https://tinyurl.com/o36m9w9 (accessed 21 November 2018).

DfE (Department for Education) (2017e) Academy Schools Sector in England: Consolidated annual report and accounts: For the year ended 31 August 2016. London: Department for Education.

DfE (Department for Education) (2018a) Mainstream Academy and Free School: Single funding agreement (March 2018 v7). London: Department for Education. Online. https://tinyurl.com/ ybab3kr9 (accessed 22 November 2018).

DfE (Department for Education) (2018b) Mainstream Academy and Free School: Supplemental funding agreement (March 2018 v6). Online. https://tinyurl.com/yb3cqdj7 (accessed 21 November 2018).

DfE (Department for Education) (2018c) Schools, Pupils and their Characteristics: January 2018. London: Department for Education.

DfE (Department for Education) (2018d) Official Statistics: Multi-academy trust performance measures: England, 2016 to 2017. London: Department for Education. 
DfEE (Department for Education and Employment) (2000) City Academies: Schools to make a difference: A prospectus for sponsors and other partners. London: Department for Education and Employment. Online. https://tinyurl.com/y77s2xa5 (accessed 22 November 2018).

Dickens, J. (2016) 'E-ACT academy chain abolishes local governing bodies'. Schools Week, 19 January. Online. https://tinyurl.com/y7zux9tu (accessed 22 November 2018).

ESFA (Education and Skills Funding Agency) (2017a) Academies Financial Handbook 2017. London: Department for Education.

ESFA (Education and Skills Funding Agency) (2017b) Financial Management and Governance Review: Enquire Learning Trust. London: Department for Education.

ESFA (Education and Skills Funding Agency) (2017c) The Rodillian Multi Academy Trust. London: Department for Education.

ESFA (Education and Skills Funding Agency) (2018) Consistent Financial Reporting Framework: 2018 to 2019: Guidance for schools and local authorities. London: Department for Education. Online. https://tinyurl.com/y8opsfsr (accessed 21 November 2018).

Foster, D. and Long, R. (2017) Regional Schools Commissioners (Briefing Paper 7308). London: House of Commons Library.

Glatter, R. (2017) '“Because we can”: Pluralism and structural reform in education'. London Review of Education, 15 (1), 115-25.

Gorard, S. (2014) 'The link between academies in England, pupil outcomes and local patterns of socio-economic segregation between schools'. Research Papers in Education, 29 (3), 268-84.

Halfon, R. (2018) Letter to Lord Agnew, 15 January 2018. Online. https://tinyurl.com/ycpcy2gn (accessed 22 November 2018).

Hatcher, R. (2018) 'The realistic possibility of a Labour Government led by Jeremy Corbyn means we could get rid of academies for good'. Forum, 60 (2), 201-16.

Helm, T. (2016) 'Tory MPs call for compulsory academies plan to be dropped from Queen's speech'. The Observer, 23 April. Online. https://tinyurl.com/jo7ybkb (accessed 22 November 2018).

HC PAC (House of Commons Committee of Public Accounts) (2018) Academy Schools' Finances: Thirtieth report of session 2017-19. London: House of Commons.

Hunt, T. (2015) Speech to ASCL annual conference, 20 March. Online. www.atl.org.uk/tristram-hunt2015-conference-speech (accessed 22 November 2018).

Levačić, R. (1998) 'Local management of schools in England: Results after six years'. Journal of Education Policy, 13 (3), 331-50.

Morris, R. (2015) 'Free schools and disadvantaged intakes'. British Educational Research Journal, 41 (4), 535-52.

NAO (National Audit Office) (2018) Converting Maintained Schools to Academies (HC 720 Session 2017-2019). London: National Audit Office.

NASUWT (National Association of Schoolmasters Union of Women Teachers) (2016) Academies: A guide for governors. Birmingham: National Association of Schoolmasters Union of Women Teachers. Online. https://tinyurl.com/yd83q9am (accessed 22 November 2018).

Newsam, P. (2017) 'What next for England's schools?'. Unpublished lecture.

OSA (Office of the Schools Adjudicator) (2015) Office of the Schools Adjudicator Annual Report: September 2014 to August 2015. Darlington: Office of the Schools Adjudicator.

OSA (Office of the Schools Adjudicator) (2016) Office of the Schools Adjudicator Annual Report: September 2015 to August 2016. Darlington: Office of the Schools Adjudicator.

OSA (Office of the Schools Adjudicator) (2018) Office of the Schools Adjudicator Annual Report: September 2016 to August 2017. Darlington: Office of the Schools Adjudicator.

Public Concern at Work (2018) Personal communication to author.

Silver, H. (1973) 'Editor's introduction'. In Silver, H. (ed.) Equal Opportunities in Education. London: Methuen.

United Learning (2018) 'United Learning governance'. Online. https://unitedlearning.org.uk/aboutus/governance (accessed 22 November 2018).

Walford, G. (2014) 'From city technology colleges to free schools: Sponsoring new schools in England'. Research Papers in Education, 29 (3), 315-29.

West, A. (2015) 'Education policy and governance in England under the Coalition Government (2010-15): Academies, the pupil premium, and free early education'. London Review of Education, 13 (2), 21-36.

West, A. and Bailey, E. (2013) 'The development of the academies programme: "Privatising" schoolbased education in England 1986-2013'. British Journal of Educational Studies, 61 (2), 137-59.

West, A., Barham, E. and Hind, A. (2011) 'Secondary school admissions in England 2001 to 2008 : Changing legislation, policy and practice'. Oxford Review of Education, 37 (1), 1-20. 
West, A. and Hind, A. (2016) Secondary School Admissions in London 2001 to 2015: Compliance, complexity and control (Clare Market Papers 20). London: London School of Economics and Political Science.

West, A. and Nikolai, R. (2017) 'The expansion of "private" schools in England, Sweden and Eastern Germany: A comparative perspective on policy development, regulation, policy goals and ideas'. Journal of Comparative Policy Analysis: Research and Practice, 19 (5), 452-69.

West, A. and Pennell, H. (1997) 'Educational reform and school choice in England and Wales'. Education Economics, 5 (3), 285-305.

West, A. and Wolfe, D. (2018) Academies, the School System in England and a Vision for the Future (Clare Market Papers 23). London: London School of Economics and Political Science.

Wolfe, D. (2011) 'Academies and the law'. In Gunter, H.M. (ed.) The State and Education Policy: The Academies Programme. London: Continuum, 19-38.

Wolfe, D. (2013) 'Schools: The legal structures, the accidents of history and the legacies of timing and circumstance'. Education Law Journal, 14 (2), 100-13.

Wolfe, D. (2014) A Can of Worms: Further restrictions on teaching creationism and pseudoscience in academies and free schools. Online. http://davidwolfe.org.uk/wordpress/archives/1502 (accessed 22 November 2018). 